\title{
Caravans, camel wrestling and cowrie shells: towards a social zooarchaeology of camel hybridization in Anatolia and adjacent regions
}

\author{
Canan ÇAKIRLAR \\ Groningen Institute of Archaeology, Rijksuniversiteit Groningen, \\ Poststraat 6, NL-9712 ER, \\ Groningen (Netherlands) \\ c.cakirlar@rug.nl \\ Rémi BERTHON \\ Archéozoologie, Archéobotanique : sociétés, pratiques et environnements \\ (UMR 7209 CNRS/MNHN), Muséum national d'Histoire naturelle, \\ 55 rue Buffon CP 56, 75005 Paris (France) \\ Archéorient - Environnements et sociétés de l'Orient ancient \\ (UMR 5133 CNRS/Université Lyon 2), \\ MSH Maison de l'Orient et de la Méditerranée - Jean Pouilloux, \\ 7 rue Raulin, 69007 Lyon (France) \\ rberthon@mnhn.fr
}

KEY WORDS

Bactrian camel, dromedary, hybrid camels, long-distance trade, congregation.
Çakırlar C. \& Berthon R. 2014 - Caravans, camel wrestling and cowrie shells: towards a social zooarchaeology of camel hybridization in Anatolia and adjacent regions. Anthropozoologica 49 (2): 237-252. http://dx.doi.org/10.5252/az2014n2a06.

\section{ABSTRACT}

Hybrid camels, intentional crosses between dromedaries and bactrian camels, are prized for their robustness and endurance. They were the prime vehicles of short and long distance caravan trade in a large area between Greece and Mongolia until the whole-scale introduction of motorized transport. This paper proposes a model for the zooarchaeological study of camel hybridization as a culture-historical phenomenon based on ethnographic and ethnohistoric observations of camel wrestling. Camel wrestling spectacles involve large audiences who gather in large arenas to watch first generation male hybrid camels wrestle during the mating season. While Anatolia was chosen as a case region for testing the model, it can be applied to all regions where hybrids are expected to occur in the archaeological record. 


\section{MOTS CLÉS \\ Chameau de Bactriane, \\ dromadaire, \\ hybrides, \\ commerce à longue \\ distance, \\ rassemblements.}

\section{RÉSUMÉ}

Caravanes, combats de chameaux et cauri : pour une approche socio-zooarchéologique de l'hybridation des chameaux en Anatolie et dans les régions limitrophes.

Les chameaux hybrides, issus du croisement intentionnel du chameau de Bactriane et du dromadaire, sont prisés pour leur robustesse et leur endurance. Jusqu’à l'introduction des véhicules à moteur pour le transport de marchandises, les chameaux hybrides étaient les meilleurs moyens de transport pour les caravanes qui permettaient de commercer à courte et longue distance dans une vaste région allant de la Grèce à la Mongolie. Basé sur des observations ethnographiques et ethno-historiques des combats de chameaux, cet article propose un modèle pour l'étude archéozoologique de l'hybridation des chameaux en tant que phénomène culturel et historique. De nombreux spectateurs se rassemblent dans de grandes arènes pour assister aux combats de chameaux mâles hybrides de première génération pendant la période de rut. Le modèle proposé a été testé en Anatolie mais peut être appliqué à toutes les régions où des restes de chameaux hybrides figurent parmi le matériel archéologique.

\section{INTRODUCTION}

The western parts of Turkey witness unusual social gatherings during short winter seasons. Amateur camel owners from all over Turkey and large numbers of local viewers gather - weather permitting every weekend at designated 'arenas' and enjoy a day-long spectacle of camel wrestling matches. Each event is a cultural anthropologist's Super Bowl that embodies diverse anthropological phenomena and processes, ranging from structured socialization, kinship organization, mediation, aggression, costly signalling, symbolism, to secularism. For the anthropozoologist, the obvious highlight is perspiring at the centre of the arena: large, first generation male hybrid camels. Astonishingly little is known about the origins and the history of these increasingly popular events and their raison d'etre, which are potentially linked to the cultural role of camel hybridization in the Old World.

In this paper we propose a model for a social zooarchaeology of camel hybridization in the Old World through a discussion of some selected elements of present-day camel wrestling in Turkey and the archaeological evidence for camels in the present territory of the Republic of Turkey. Our model suggests that, given the importance of hy- brid camels in the caravan trade until recent past and the requirement to cross Bactrian studs with dromedary females to attain them, social events similar to present-day camel wrestling spectacles may have facilitated acculturation processes by bringing together groups from diverse backgrounds. Although our review of archaeological camel finds in Turkey shows that it is difficult to test this model with current zooarchaeological evidence, our study indicates that camel wrestling events have previously unrecognized potential to stimulate and channel future studies of camel hybridization.

\section{CURRENT OSTEOARCHAEOLOGICAL KNOWLEDGE OF HYBRID CAMELS}

Reconstructing the history of camel hybridization depends largely on the identification of their remains in ancient cultural contexts (Potts 2004). Bones and teeth of Old World Camelidae (hereafter camel) are readily identifiable, even in the fragmented faunal assemblages that usually represent a multitude of species. But, although the cultural importance of identifying whether both or either of the two geographically separate species - dromedary (Camelus dromedarius) and Bactrian camel (Camelus bactrianus) — are present in a given site has been recognized relatively early on (Compagnoni \& Tosi 
1978; Wapnish 1984), distinguishing them based on their skeletal remains has proved challenging (Boessneck \& von den Driesch 1975, 1985). Soon after, the rapid intensification of zooarchaeological research into the protohistoric and historic periods of Southwest and Central Asia and the increased interest in the domestication history of camels (Peters \& von den Driesch 1997; Peters 2001) led to comprehensive osteomorphological studies on modern specimens. These studies have shown clear non-metric osteomorphological differences between almost all the skeletal elements of the two species (Wapnish 1984; Steiger 1990). Moreover, it has been established that dromedary bones are more slender than those of Bactrian Camels, reflecting the latter's visibly more sturdy build (Lesbre 1903; Wapnish 1984; Köhler-Rollefson 1989; Steiger 1990; Uerpmann 1999; Peters 2001; Becker 2008).

Despite all these careful considerations of the osteological differences between the two species, zooarchaeologists remained for a long time reluctant to investigate the possibility of the presence of hybrids in the archaeological record. In view of the culture-historical significance of hybrid use (Potts 2004; Buillet 2009), this situation is intriguing. Theoretically, hybrid presence is, if not inevitable, extremely likely for any time period and region where the human-induced geographical overlap between the two species is expected. Köhler-Rollefson's study (1989) on the camel skeletons from the Early Islamic layers of Pella in Jordan may be the first discussion that gives the issue due consideration. At Pella, a well-preserved assemblage of camel skeletons found in a closed archaeological context provided Köhler-Rollefson with a unique laboratory to explore the possibility of hybrid occurrence in this historically acknowledged trade centre. Hybrids of any two animal species are generally distinguished by calculating indices that have diagnostic value in order to establish a relative comparison of body dimensions and by identifying how mixed features appear (Reitz \& Wing 2008: 190). In addition to these potential hybrid traits, hybrid camels are marked by their extraordinary size, caused by a genetic condition called heterosis (Baimuranov 1989). In the case of the camel skeletons from Pella, the unusually large size of the skeletons and the presence of mixed cranial features in one of them led Köhler-Rollefson to suggest the highly probable presence of hybrids in Pella.

All subsequent discussions for probable occurrences of hybrid camels in archaeological deposits rely on similar arguments of size and mixed morphology (Fabiš 1996; Mashkour 1997; Uerpmann 1999; Becker 2003; Studer \& Schneider 2008; Pigière \& Henrotay 2011). What exact traits stand for mixed non-metric morphology, however, remains to be established. Mixed non-metric osteomorphological features are difficult to pinpoint and quantify in all hybrids. Attempts at defining these are complicated by differences among parental breeds, random inheritance and filial generation (i.e. whether the parents are distinct species or hybrids). Such problems have been largely overcome for the hybrids of other animals that were subject to osteoarchaeological research thanks to the availability of large amounts of modern specimens (e.g. for mules, the F1 hybrid of horse and donkey, see Peters 1998). The exact opposite is the reason for the rather slippery ground on which the osteological study of hybrid camels still stands (Studer \& Schneider 2008; Pigière \& Henrotay 2011). "As [hybrids]... no longer exist, it is impossible to obtain fresh skeletal material for comparative purposes" (Uerpmann 1999). As we will demonstrate, one by-product of present-day camel wrestling, namely the skeletons of wrestling camels, may solve this problem. But, as we will also try to demonstrate, camel wrestlers may hold more clues to the archaeology of hybrid camels than merely providing keys to defining hybrid camel bones.

\section{ANCIENT AND MODERN EVIDENCE FOR THE PRESENCE OF CAMEL HYBRIDS IN TURKEY}

\section{ETHNOARCHAEOLOGY OF CAMEL WRESTLING}

The following brief ethnoarchaeological account of wrestling camels and camel wrestling matches is based on informal interviews with informants from the province of Aydın in western Anatolia, anthropological and popular publications on camel wrestling, mentions of these cultural events in publications on the history and anthropology of 
camels, and Çakırlar's observations at camel wrestling spectacles. In addition to these, information was extracted from the published diary of Mehmet Üzüm, who was a camel owner from the Yörük village of Özbaş in the province of Aydın during the first half of the 20th century (Üzüm 2003).

All informants come from Aydın and include young and middle-aged amateur camel owners from Söke, manufacturers of processed camel meat from İncirliova, and elderly (70-75 years old) former camel herders from the Yörük village of Özbaş near Söke. Since Aydın is the centre of modern-day camel wrestling in Turkey (Çalışkan 2009), we hold this group of informants a representative sample for our purposes. All informants were male. Apart from forming a small group among the spectators at wrestling events, women have little to do with present-day camels or camel wrestling in western Turkey.

The necessity to produce individual observations of present-day camel wrestling resulted from the inadequacy of ethnoarchaeologically relevant information provided by the recent social and cultural anthropological accounts of these increasingly popular events (Çalışkan 2009; Çulha 2008; Donlon et al. 2010). These scholarly articles handle modern-day camel wrestling holistically and mostly in terms of its potential for heritage tourism. Other than these scholarly publications, one of the most accurate descriptions of present-day camel wrestles is presented by S. Gülsöken in his vividly illustrated popular photo-journalism book (Gülsöken 2010). None of these works attempt to approach their discussions from a historical viewpoint.

This is admittedly because information on the history of camel wrestling is painfully sparse. The famous 17 th century traveller Evliya Çelebi reports about all sorts of curiosities (some untrue) that occurred in the then vast Ottoman territory and neighbouring lands, but provides no account of camel wrestling (Çelebi 1985). Early western travellers to Anatolia also mention camels, but not camel wrestling (e.g. Oddens 2009). Present historiography focuses primarily on camels' role in caravan trade (Faroqhi 1988). Despite the scarcity of textual evidence on camel wrestling, it is difficult to imagine that modern-day camel wrestling popularly claimed to be a tradition - is without historical background. Many aspects of Ottoman history remain off the record unless the Ottoman state was directly involved and camel husbandry was probably one of them (Faroqhi 1988). Most of the information on Ottoman animal husbandry derives from tax records, which provide no specifics about the social meaning of the species that were bred. While textual records remain silent about what we are interested in, pictorial sources, although likewise rare, prove more useful in the quest for the historical evolution of camel wrestling (see below).

Out of the colourful and complex picture of camel wrestling that emerges from the scarce historical evidence and the modern source categories mentioned above, we deducted six elements that are potentially of greatest explanatory power for the social zooarchaeology of hybrid camels: animal subjects, human subjects, location, time, environment, and related commodities.

The animal subjects of the present-day camel wrestling in western Turkey consist exclusively of hybrid males in rut. There are several varieties of hybrid camels, each denominated with a Turkic name that is part of an established folk nomenclature. This folk nomenclature is in use (or was until recently) across a vast area spanning from Kyrgyzstan to the former Ottoman territories in the Balkans (Buillet 1990: 144-145). Table 1 displays the variety of camel hybrids and the nomenclature used in describing them in present-day western Anatolia. It is astonishing to observe that terminology is almost identical to others used in a variety of regions in Middle and West Asia as well as those cited by early modern travellers (Burckhardt 1830; van Lennep 1870; Tapper 1985). First generation (F1) male hybrids from male Bactrian camel progenitors are the preferred type in present day wrestling in western Anatolia. Being stronger than both parents, F1 females and males seem to have been in demand in the in western Anatolian caravan trade until the wide introduction of motorized vehicles in the mid20th century (Üzüm 2003). While all F2 varieties between an F1 and either a dromedary or Bactrian camel are considered acceptably useful as pack animals, true second generation hybrids (F2x) are considered, according to informants from Özbaş, 
TABLE 1. - Extant and remembered breeds of camel hybrids in Anatolia (based on informants' accounts). Abbreviation: $\boldsymbol{C}$., Camelus.

\begin{tabular}{llll}
\hline Generation & Common Name & Female progenitor & Male progenitor \\
\hline F1 & Tülü & Tek hörgüçlü deve (C. dromedarius) & Çift hörgüçlü deve (C. bactrianus) \\
F2a & Yeğen & F1 (Tülü) & Bactrian \\
F2b & Tavsi & F1 (Tülü) & Dromedary \\
F2c & Teke & Dromedary & F1 (Tülü) \\
F2x & Kükürdi & F1 (Tülü) & F1 (Tülü) \\
F3 & Kerteles & (F2c) Teke & Bactrian \\
\hline
\end{tabular}

"a menace to the mother and the herd". True F2s are degenerated in both physiology and behaviour (Baimuranov 1989).

Today's wrestling camels are reportedly 'imported' from Iran. It may be wise, however, to approach this provenance with some caution. These camels may be imports from farther east from Iran. After all, the Bactrian camel itself was named after the region where it was first encountered, not after the region where the two-humped camels are thought to be endemic (Peters \& von den Driesch 1997; Potts 2004). Although hybrid camels were bred in Iran at least until the Islamic Revolution (Tapper 1985), we have no knowledge about the present situation (pers. comm. M. Mashkour). According to other researchers, hybrid camels are exported from diverse countries in Middle Asia, including Afghanistan (Gülsöken 2010: 36) and Turkmenistan (Çalışkan 2009). According to Çalışkan (2009), some are even bought from the semi-nomad Yörük tribes who still roam the western Taurus. In the absence of legal tax records (because wrestling camels are not imported according to customs regulations), there is no way, other than by using isotopic (e.g. strontium) or DNA analyses, of knowing exactly where the Turkish wrestling camels originate from.

Regardless of problematic origins, the information that, if not all, the great majority of wrestling camels are not bred in Turkey holds true. Yet, it seems that breeding hybrids did take place in western Anatolia until recently (Gülsöken 2010: 66). Our elderly informants confirm this by stating that pure-blood Bactrian camel males did exist in the area until the last days of caravan trading, but these were rare and priced animals. They were true studs, kept exclusively for the purpose of generating hybrids and too precious to be used in ordinary caravan activity. The proud owners of these Bactrian camels were respected men of special status who travelled from village to village (according to informants) or would be stationed at the yaylas (upland seasonal pastoralist camps) where they would let their studs receive female visitors (Gülsöken 2010: 66). Nowadays informants confirm records from the first quarter of the 19th century. Burckhardt (1830: 110-111) reported that pure-blood Bactrian camel males, imported from the Crimea, were kept in Anatolia exclusively for breeding. The Swiss traveller was informed by Arabs with whom he stayed in Syria but did not check this information himself in Anatolia. The proposition that pure-blood Bactrian camel females were not kept in Anatolia is challenged by van Lennep (1870: 162-164). In 1864, van Lennep observed Bactrian camel females in north central Anatolia and later suggested that they were used to keep the Bactrian camel species pure. Either way, contradictory information does not suffice to clarify whether the Bactrian camel studs themselves were bred in western Anatolia and/or in neighbouring regions or whether a constant supply of pure Bactrian camel males from lands closer to their accepted geographic range was maintained also in the earlier periods of hybrid exploitation in Anatolia.

The human subjects of present-day camel wrestling activities appear to be not all too concerned with the provenance and the genetic characteristics of the animals subjects of the 'games'. While most owners prefer not to elaborate on how they acquired their wrestling camels, spectators, which often include high-ranking government officials, do not appear to be particularly interested in these issues. 
It is difficult to classify the participants - spectators, owners, caretakers - into rigidly defined subgroups. They are simply too many: the town of Selçuk holds a Guinness World Records certificate in 2005 for having attracted "the largest audience at a camel wrestling" in $1994^{1}$ Moreover, the rapidly changing nature of present-day camel wrestling culture requires maintaining greater caution when it comes to characterising the participants' societal identities and roles. In light of our interviews and published accounts, however, some aspects pertaining to the human subjects of the phenomenon appear more persistent than others. For example, while camel ownership, as an institution, is beginning to pass on to relatively wealthy industrial crop farmers and their sons, almost all caretakers are descendants of former camel keepers of Yörük origin. Less wealthy camel owners themselves are of Yörük origin as well. Since some of the earliest Ottoman records on the Yörük of western Anatolia mention camel breeding and the camel caravan trade as the main occupations of the Yörüks in this area in the 16th century AD (Karaca 2008), it is not at all surprising that these formerly nomadic people still constitute the backbone of present-day camel-related activities.

Ethnic origin is arguably the most defining characteristic of the former actors of camel ownership and wrestling in Anatolia. It is common knowledge that the Yörük represent a group of Turkic tribes who maintained their strict transhumant pastoralist existence upon converting to Islam and arriving in Anatolia. Going back to the issue of the provenance of the animal subjects, it may be surmised that some Yörüks, who retained a physical bond with the fatherland through their involvement in the caravan trade, were also responsible for the trade in true-blood Bactrian camels. However they may have retained their stock, it is clear that it is these formerly nomadic people who continue to hold the traditional expertise required for camel breeding.

Nevertheless, despite strong mobile elements in the history of hybrid camel keeping, present-day camel wrestling is centred on the littoral plains of western Anatolia. Most camel owners are town dwellers. Some keep their camels in garages, occa-

1. http://www.selcuk.bel.tr/tr/index.php?page=belediyehaber detay\&haber_id=44. Accessed 10.04.2012. sionally taking them on long walks along inter-city highways. Those who own arable land keep their camels in larger stables on their farms.

Wrestling events, on the other hand, take place in designated areas outside town centres, to where camels are transported, rather ironically, in trucks. Wrestling arenas are rudimentary structures with no formalized dimensions or proportions. Wrestles take place every weekend in another arena during winter months, compelling dedicated fans to travel sometimes considerable distances in order to participate in the events.

With constant relocation, the wrestling culture regains its mobile character and, more significantly, reassumes its power to congregate individuals with diverse social backgrounds around an emotional fanaticism for rutting camels. A prime example of the complex bond between domesticated animals and humans, this particularly moving aspect of the wrestles, probably more alive today than ever, is the essence of our hypothesis that archaic forms of camel wrestling must have played a role in the social history of camel hybridization. As we discussed above, text-based history provides little definitive evidence towards proving this hypothesis, but art history seems to offer a bit more.

One of the earliest indisputable representations of camel wrestling in an anthropogenic context is a 15th century miniature found in the archives of Topkap1 Palace (Fig. 1). The miniature depicts two camels entangled by their necks (Adamova 2004: fig. 2). They neither have the double hump typical of the Bactrian camels nor the pronounced pointed hump typical of the dromedary. This probably attests to their hybrid nature. What is more interesting is the diverse ethnic backgrounds of the men surrounding the wrestling camels. In the scene, there are two caretakers, each controlling a camel with a long rope. These have the characteristic looks of the Turco-Mongolian or Chinese. The two additional male characters in the drawing, presumably spectators, are doubtlessly aliens: one is clearly of African descent and the other is a likely Caucasian. While the appearances of the caretakers may be deceiving because oriental miniatures dictate that all depicted humans should bear recognizable Turco-Mongolian or Chinese features, it 


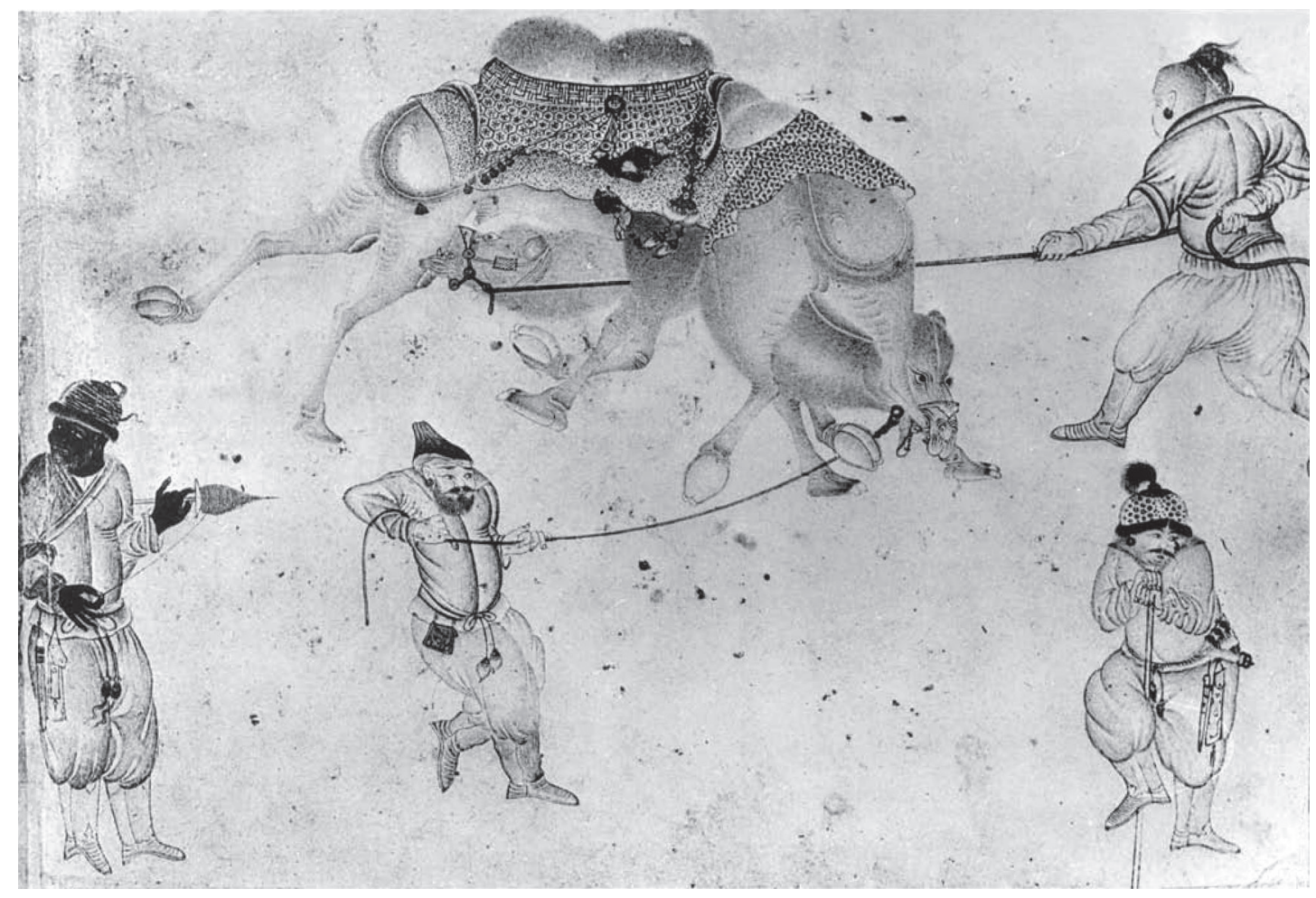

FIG. 1. - Drawing, second half of the fifteenth century, Istanbul, Topkapı Sarayı Library (After Adamova 2004: fig. 2).

is clear that the artist's depiction of the onlookers' non-Asian origins was a deliberate and successful attempt to highlight the foreign origins of these men. Although it is difficult to say more without straying into speculations, the intention of the artist to represent an 'international' ambiance is undeniable. If present-day camel wrestling activities lack this kind of diversity, and they do in many ways, this situation is probably related to post-republican policies in Turkey towards cultural homogeneity as opposed to a historic practice.

Distinguishing tradition from discontinuities is less complicated when it comes to issues relating to the timing of camel wrestling. While organizing wrestles on weekends must be a relatively recent convention, brought into effect by modern work schedules, the season during which the wrestles take place could not possibly have been a matter of preference. Like many other ungulates with distributions in temperate regions, the breeding season for camels coincides with the cold months between December and March, during which the animals display rutting behaviour. Testosterone concentration, a likely cause of aggressive behaviour, in male dromedary blood is ten times higher from January to late March than during the rest of the year (Yagil \& Etzion 1980). What we call wrestling is this ritualized rutting act that happens between males, two at a time. Certain physiological requirements of camels, such as short breeding seasons and failure to artificially stimulate breeding instincts, still pose major difficulties in camel reproduction for commercial purposes (Skidmore et al. 2010). The cold and rainy breeding season may be the major reason why Bactrian camel stud keepers started to offer their services at lowland plains rather than receiving 'customers' at their camps (Leese 1927). Although winter is the only season when wrestling can take place biologically, it would be misleading to assume that it is the camel owner's ultimate spring. 
Cancellations of wrestling events due to adverse weather conditions are not rare. The negative effects of bad weather, especially rain, on camel transport and transportation of camels must have been more severe in western Anatolia during pre-modern periods. Üzüm frequently revisits the theme of floods preventing camel caravans from transporting cargoes in his diary (Üzüm 2003). Naturally, such floods would also prevent camels to be transported to gathering places for the wrestling until recent past.

Today, regardless of their origin and the various directions they travel across western Anatolia, a few exceptions aside, the final destination of all camels in Turkey is the town of Incirliova, where they are processed in specialized slaughterhouses. Here, meat from old and sick camels are processed to produce sucuk, a strongly spiced sausage suited for dry and (if available) cool storage. According to Çalışkan (2009), camel sausage manufacture at this location dates back to the early 20th century. Recommendations of Al-Arbuli, the author of a 15th century Andalusian treaty on food, to cook dromedary meat with hot spices (Diaz-Garcia 1983) implies that the tradition of spicing camel meat was wide-spread and goes earlier. While it could be argued that most Andalusian food tends to be spicy and that the curing of camel meat represents thus no exception, it is equally plausible that curing, spicing and air-drying were among the early methods applied by nomadic camel keepers to preserve excess camel meat. Camel sucuk is then sold at local markets and camel wrestling events.

A few other commodities play a role in the lives of wrestling hybrid camels in western Anatolia. The most tangible (and thus archaeologically relevant) of these are the cowrie bead ornaments that adorn the large competitors. With few or no exceptions, each camel arrives at the arena with a formal set of decorations including beadworks. Cowrie beads are knitted into their elaborate saddles and halters. Astonishingly, some camel owners (male) stated that they knit the beads themselves instead of their traditionally more experienced female members of their immediate community. A less visible commodity pertaining to wrestling camels is bitter vetch (Vicia ervilia). Bitter vetch is one of the earliest domesticated grain legumes and is known for its animal fodder qualities rather than its usage in direct human nourishment (Halstead \& Jones 1989; Zohary \& Hopf 2000). Today, it is used in Turkey exclusively as animal feed. This high energy provider is the preferred element in wrestling camels' expensive diet today and it was fed to caravan camels as well (Üzüm 2003).

From its animal subjects in the centre to less obscure by-products, modern-day camel wrestles represent a complex and ever evolving cultural microcosmos. While its present uprooted state and close link to nomadism make it difficult to define its historic forms, scarce but remarkable art historical evidence indicates that detailed investigations into the distant origins of wrestling will be rewarding. Since one of the main aims of domesticating and keeping camels, and breeding hybrids when possible was to create powerful beasts of burden, it is highly likely that earlier forms of spectacle involving rutting camels were part of a mechanism that enhanced selective breeding and evolved synchronously with the history of camel hybridization. Nature dictated the majority of the rules, including the requirement for pure-bred parents which brought diverse peoples together and to lands far away from their own.

But how can we convert this wealth of information into a model that will improve the archaeology of camel hybridization? A survey of evidence and discussions on the archaeology of camels in Anatolia, taken as a regional case study, will provide a baseline to construct the answer to this question.

\section{ZOOARCHAEOLOGICAL EVIDENCE FOR CAMELS} IN ANATOLIA

A general paucity of domestic camel remains is evident in the archaeological record of Eurasia and Anatolia is no exception. Several factors are responsible for the scarcity of excavated camel remains. In contrast to most other domesticated animals (for example pigs), meat can be considered of secondary importance. Camels are kept primarily as beasts of burden and/or for their milk (Buillet 1990; Horwitz \& Rosen 2005; Reitz \& Wing 2008: 295-296; Wilson 1984: 5-14). Consequently, camel bones rarely end up in everyday kitchen refuse, which make up the largest proportion of archaeological deposits uncovered in Eurasia. Another cultural 


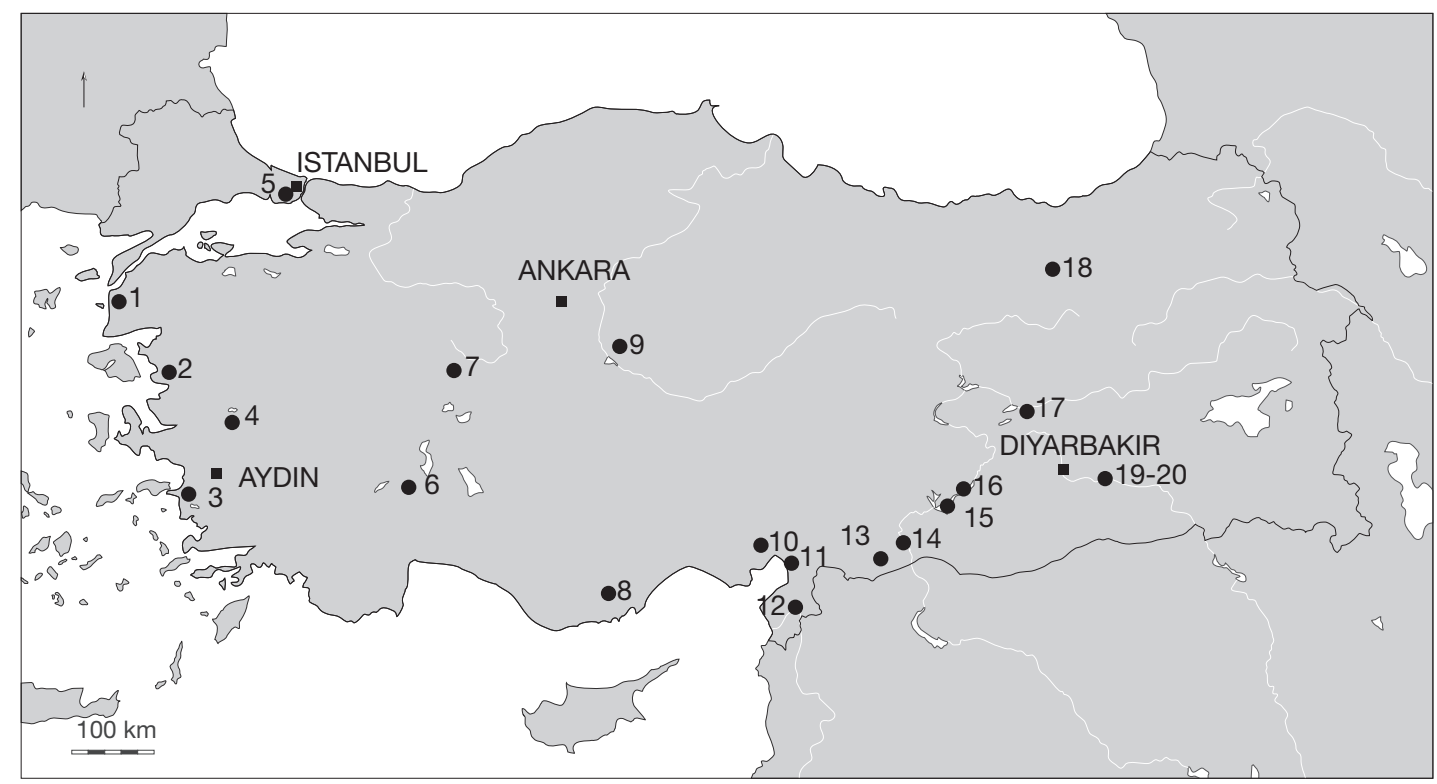

FIG. 2. - Location of place names mentioned in the text (circles, ancient place names, numbers refer to sites according to Table 2; squares, modern place names).

explanation for the rarity of camel remains may be related to camels' use by specialized nomadic groups. Identifying the archaeological signatures of ephemeral and mostly perishable material elements of mobile cultures is among the biggest challenges of archaeology. It is likely that in some regions, camel meat was consumed mainly at camps located outside permanent settlements. This strong possibility increases the significance of archaeological camel remains from permanent settlements. A third reason for the paucity of camel remains in archaeological contexts has to do with methodologies, or rather their poor utilization. Failure to collect animal remains from post-Bronze Age sites in Anatolia and to facilitate their scientific study continues to be one of the unfortunate realities of archaeology as practiced in Turkey. We consider this methodological shortcoming to have the most important negative impact on the almost empty map of archaeological camel finds in Anatolia (Fig. 2).

While far from complete, the map of Anatolian camel finds and the descriptions of camel remains by individual researchers have important implications. First of all, the map, which displays infor- mation compiled from various sources including 'grey literature' and personal communications we see that camels were distributed from İstanbul to Diyarbakır, all across the present territory of the Turkish Republic. Chronological details (Table 2) provide further insights into the distributional patterns of camels in Anatolia. Almost all studied post-Bronze Age zooarchaeological assemblages from Turkey include camel remains. Although the earliest occurrences of Bactrian camel in north Mesopotamia could date back to the 13th century BC (Becker 2008), the second millennium BC finds from Lidar Höyük in southeastern Turkey (Kussinger 1988) should be seen as outliers representing intrusions. The earliest camel remains from chronologically secure contexts in Turkey date to the second quarter of the 1 st millennium BC (Vogler 1997, Ikram \& Çakırlar 2003, Çakırlar \& Rossel 2010). The introduction of domestic dromedary to the Southern Levant is now accurately dated to the last quarter of the 10th century BC (Sapir-Hen \& Ben-Yosef) and we are convinced that this event preceded the spread of this species in Anatolia. The locations of camel remains finds 
TABLE 2. - Gazetteer of archaeological camel remains from Turkey. Sites are sorted in a West to East order (see Figure 2).

\begin{tabular}{|c|c|c|c|c|c|c|c|}
\hline 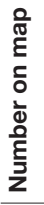 & 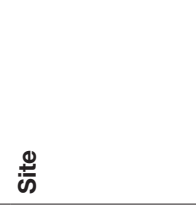 & $\begin{array}{l}u \\
\stackrel{0}{ \pm ँ} \\
0\end{array}$ & $\begin{array}{l}\frac{7}{\pi} \\
\frac{\pi}{0} \\
\stackrel{\Phi}{2} \\
\text { है } \\
\text { Dे }\end{array}$ & 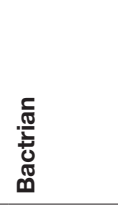 & $\begin{array}{l}\text { 은 } \\
\text { 흘 } \\
\text { 지 }\end{array}$ & $\begin{array}{l}\frac{0}{0} \\
\text { की } \\
\frac{3}{0} \\
\frac{8}{0}\end{array}$ & 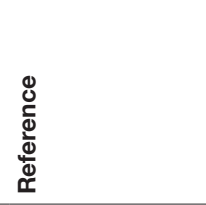 \\
\hline 1 & Troy & Roman & & & $\begin{array}{l}1 \text { (1st phalanx, based } \\
\text { on metrical and } \\
\text { morphological analysis) }\end{array}$ & & Fabiš 1996 \\
\hline 2 & Pergamon & $\begin{array}{l}\text { 12th-15th } \\
\text { century AD }\end{array}$ & & & Not discussed & $\begin{array}{l}1 \text { (os carpi } \\
\text { radiale) }\end{array}$ & $\begin{array}{l}\text { Boessneck \& } \\
\text { von den Driesch } \\
1985\end{array}$ \\
\hline 3 & $\begin{array}{l}\text { Kalabak Tepe } \\
\text { (Millet) }\end{array}$ & $\begin{array}{l}\text { 7th to } 5 \text { th } \\
\text { centuries BC }\end{array}$ & 2 & & Not discussed & & Peters 1993 \\
\hline 4 & Sardis & $1000-547 \mathrm{BC}$ & & & Not discussed & 19 & Deniz et al. 1965 \\
\hline 5 & Yenikapı & $400-1400$ AD & $\begin{array}{l}\text { At least } 1 \text { in situ } \\
\text { skeleton dated to } \\
\text { the end of the } 5 \text { th } \\
\text { century } A D\end{array}$ & $\begin{array}{l}\text { Not } \\
\text { detected }\end{array}$ & Not discussed & $\begin{array}{l}100 \text { (some } \\
\text { with butch- } \\
\text { ery marks) }\end{array}$ & Onar et al. 2010 \\
\hline 6 & Sagalassos & Roman & 1 & & Not discussed & & $\begin{array}{l}\text { De Cupere 2001: } \\
65-66 .\end{array}$ \\
\hline & & Medieval & & & Not discussed & 1 & Silitlibolaz 2009 \\
\hline 7 & Amorium & Medieval & & & & $\begin{array}{l}10 \text { camel } \\
\text { mandibles } \\
\text { in a single } \\
\text { context }\end{array}$ & $\begin{array}{l}\text { Silitlibolaz, } \\
\text { pers. comm. } \\
2010\end{array}$ \\
\hline 8 & Kilise Tepe & $\begin{array}{l}\text { Iron Age (1150- } \\
650 \mathrm{BC})\end{array}$ & & & Not discussed & 3 & Baker 2008 \\
\hline 9 & $\begin{array}{l}\text { Kaman- } \\
\text { Kalehöyük }\end{array}$ & Ottoman & 9 & 1 definite & $\begin{array}{l}1 \text { possible (as large as } \\
\text { hybrid from Pella see } \\
\text { Köhler-Rollefson 1989) }\end{array}$ & 18 & Hongo 1994 \\
\hline 10 & Sirkeli & $1000-500 \mathrm{BC}$ & 4 bones & & Not discussed & & Vogler 1997 \\
\hline & Kinet & $800-650$ BC & & & & 2 & $\begin{array}{l}\text { Ikram \& Çakırlar } \\
2003\end{array}$ \\
\hline 11 & $\begin{array}{l}\text { Hisn-al Tinat } \\
\text { (Kinet's outlying } \\
\text { Islamic settle- } \\
\text { ment) }\end{array}$ & $\begin{array}{l}\text { 8th to } 10 \text { th } \\
\text { century } A D\end{array}$ & & & $\begin{array}{l}\text { 1st phalanx. Tentatively } \\
\text { identified as a hybrid }\end{array}$ & & $\begin{array}{l}\text { Eger } 2010 \text { (faunal } \\
\text { assemblage } \\
\text { studied by } \\
\text { Çakırlar) }\end{array}$ \\
\hline 12 & Tell Atchana & $\begin{array}{l}\text { Possibly Early } \\
\text { Iron Age }\end{array}$ & & & Not discussed & 1 & $\begin{array}{l}\text { Çakırlar \& Rossel } \\
2010\end{array}$ \\
\hline 13 & $\begin{array}{l}\text { Tilbeşar } \\
\text { Höyük }\end{array}$ & $\begin{array}{l}\text { Medieval 11th- } \\
\text { 13th cent AD }\end{array}$ & & & $\begin{array}{l}\text { One distal humerus is } \\
\text { discussed based on } \\
\text { several measurements } \\
\text { ratios and could be an } \\
\text { hybrid }\end{array}$ & 10 & $\begin{array}{l}\text { Berthon \& } \\
\text { Mashkour } 2008\end{array}$ \\
\hline
\end{tabular}

in Turkey cluster in the southeastern part of the country along the most likely routes of contact with Syria and other regions in Southwest Asia. But this inference may be biased because many of the sites yielding camel remains are located along the Euphrates River where several salvage archaeological operations were conducted prior to dam constructions. 
TABLE 2. (end) - Gazetteer of archaeological camel remains from Turkey. Sites are sorted in a West to East order (see Figure 2).

\begin{tabular}{|c|c|c|c|c|c|c|c|}
\hline 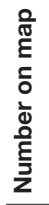 & $\stackrel{ \pm}{\infty}$ & 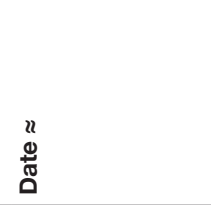 & 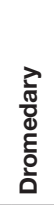 & 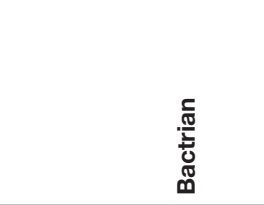 & $\begin{array}{l}\text { 끈 } \\
\text { 흘 } \\
\text { 조 }\end{array}$ & 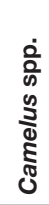 & 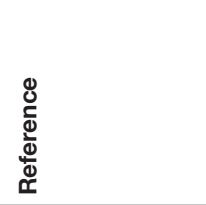 \\
\hline \multirow{3}{*}{14} & $\begin{array}{l}\text { Apamée } \\
\text { (Urfa ili) }\end{array}$ & $\begin{array}{l}\text { Hellenistic 3rd-1st } \\
\text { cent BC }\end{array}$ & & & & 1 & Mellet 2008 \\
\hline & \multirow[t]{2}{*}{ Zeugma } & $\begin{array}{l}\text { Byzantine } 6 \text { th and } \\
\text { 7th cent } A D\end{array}$ & & & & 10 & $\begin{array}{l}\text { Mellet 2008, } \\
\text { Rousseau 2006, } \\
\text { Rousseau et al. } \\
2008\end{array}$ \\
\hline & & $\begin{array}{l}\text { Early roman 1st } \\
B C-2 \text { nd } A D\end{array}$ & & & & 1 & $\begin{array}{l}\text { Rousseau 2006, } \\
\text { Rousseau et al. } \\
2008\end{array}$ \\
\hline \multirow{5}{*}{15} & \multirow{5}{*}{ Lidar Höyük } & Early 2nd mill. BC & & \multirow{5}{*}{$\begin{array}{l}2 \text { specimens identified } \\
\text { as dromedary }\end{array}$} & \multirow{5}{*}{ Not discussed } & 1 & \multirow{5}{*}{ Kussinger 1988} \\
\hline & & Late 2nd mill. BC & & & & 1 & \\
\hline & & Early 1st mill. BC & & & & 12 & \\
\hline & & $300 \mathrm{BC}-300 \mathrm{AD}$ & & & & 74 & \\
\hline & & Medieval & & & & 63 & \\
\hline 16 & Hassek Höyük & $\begin{array}{l}\text { Hellenistic-Ro- } \\
\text { man }\end{array}$ & & & Not discussed & 1 & Stahl 1989: 110 \\
\hline 17 & Korucutepe & Medieval & & & Not discussed & 1 & $\begin{array}{l}\text { Boessneck \& von } \\
\text { den Driesch } 1975\end{array}$ \\
\hline 18 & Büyük Tepe & Iron Age & & & & 1 & $\begin{array}{l}\text { Howell-Meurs } \\
2001\end{array}$ \\
\hline 19 & Ziyaret Tepe & $\begin{array}{l}\text { Medieval 13th- } \\
\text { 15th cent AD }\end{array}$ & 1 & 2 & $\begin{array}{l}\text { Carpal bones (mixture } \\
\text { of morphological } \\
\text { characters could } \\
\text { indicate hybrids) }\end{array}$ & 2 & $\begin{array}{l}\text { Berthon, } \\
\text { unpublished }\end{array}$ \\
\hline \multirow[t]{2}{*}{20} & \multirow[t]{2}{*}{ Kavuşan Höyük } & $\begin{array}{l}\text { Medio-Assyrian } \\
\text { 13th-11th } \\
\text { cent. BC } \\
\end{array}$ & & & \multirow[t]{2}{*}{ Not discussed } & 1 & \multirow[t]{2}{*}{ Berthon 2013} \\
\hline & & $\begin{array}{l}\text { Neo-Assyrian } \\
\text { 9th-7th cent. BC }\end{array}$ & & & & 1 & \\
\hline
\end{tabular}

Secondly, our survey shows that camels were rapidly spread across Anatolia not too long after their introduction. Camel remains found at Büyüktepe in northeast Anatolia (Howell-Meurs 2001) indicate that camels had reached relatively remote and rougher terrains as early as mid 1st millennium BC. Camel finds at Sardis located in the central eastern Aegean (Deniz et al. 1965), and Kabalak Tepe further west on the Aegean coast - as a matter of fact, near Söke - (Peters 1993) dated to the 5 th and 4th centuries $\mathrm{BC}$, roughly corresponding to the Persian infiltration that reached all the way to Greece or even earlier. They indicate that camels were in use probably all across Anatolia by this time.

As expected on the basis of abundant evidence for camels even in the European territories of the Roman Empire (Morales Muniz et al. 1995; Bartosiewicz \& Dirjec 2000; Pigière \& Henrotay 2011), camel remains from Roman contexts are found at even more westerly lying regions of Anatolia, for example at Troy (Fabiš 1996). Camels become more abundant in Late Roman 
and Medieval times. Although it may appear that they are more common in the eastern parts of Turkey during Medieval times, this is probably due to the better state of research in this region. Medieval camel remains are ubiquitous in regional trade centres along the Euphrates and Tigris rivers. One intriguing exception is the absence of camels at Medieval Gritille, across the river from Lidar Höyük where a total of 63 camel specimens were identified in the Medieval layers (Kussinger 1988; Stein 1988). According to Redford (1998: 269-271), Lidar Höyük was a trade centre settled during the early Islamic Period, whereas Gritille lived its heyday during the 11 th and 12 th centuries $\mathrm{AD}$, when Christians were dominant in the region and the basin served as a 'breadbasket' for Urfa. The absence of camel remains at Crusader Period Gritille and their abundance at Islamic Period Lidar Höyük could imply that there were either breaks in the trade in camels depending on the course of international relations or that different religious/ethnic groups had different preferences in camel consumption in Medieval highland Anatolia. But with such scanty evidence from two sites, it is impossible to go beyond speculations about this topic.

Thirdly, the reported details of the camel remains generally suggest that the presence of hybrids was either not investigated or not considered. Most of the camel remains were identified at the generus level. The majority of the remaining specimens were ascribed to the dromedary, although a few Bactrians camels were also detected, notably at sites located near the southeastern borders. There is an obvious increase in the number of species-levels identifications after Steiger's osteomorphological study on the distinguishing post-cranial features of C. dromedarius and C. bactrianus. It is roughly from this point onwards that researchers started considering the possible occurrence of hybrids along with pure breeds. If these identifications are correct, hybrid camels were present in the northwestern corner of Anatolia already in the Roman Period (Fabiš 1996). In the absence of a more accurate method to identify hybrids, claims for hybrids in Anatolia, like elsewhere, are based on the large size of their remains but also on the presence of mixed morphological features.

The final remark we would like to make based on our survey of camel remains from archaeological sites in Turkey, is the decontextualized manner in which they have been reported. For the vast majority of the remains, the only contextual information we have are rough dates, in some cases spanning up to a thousand years. While it is highly probable that most of the camel remains were recovered from fill and other deposits that yielded no notable finds other than kitchen refuse, there is no way of proving or refuting this. The recent find of ten camel mandibles from a single context in Medieval Amorium may be a case in point hinting at what valuable contextual information we may be missing (Silitlibolaz, pers. comm.). Do the Amorium mandibles represent centralized butchering of camels, similar to that practiced today in İncirliova?

The present archaeological evidence in Anatolia for camels in general and hybrid camels in particular is far from sufficient to prove the hypothesis that camel breeding, use and exchange in ancient Anatolia involved camel wrestling like social gathering events that brought together international participants who were partners in long distance trade across Eurasia. Below in the last section of this paper we suggest a method to develop the state of research into the social and cultural history of camels in Anatolia and elsewhere in the region.

\section{A NEW APPROACH TO THE ARCHAEOLOGY OF HYBRID CAMELS}

A thorough investigation of the occurrences of hybrid camels and their cultural-historical meaning can start with tackling the animal subjects. Hybrid camel breeding does not belong to history in western Turkey. Considering the growing demand for hybrid camels in Turkey, it is an expanding business - somewhere in Persia or beyond. Although of unknown provenance, hybrid camels living in western Turkey are relatively easy to acquire. Individuals of wrestling male hybrids can become the much needed 'type specimens' of comparative osteomorphological studies of camels and solve the problems encountered in identifying the ar- 
chaeological hybrids. The problem of provenance, and thus the problem of parental genealogy can be solved by conducting DNA analyses on hard and soft tissues of the modern specimens.

But solving the problem of differential camel osteomorphology is not sufficient to understand the cultural-historical meaning of established hybrid remains. The survey of archaeological camel remains from Turkey showed that isolated zooarchaeological considerations of camel remains add little to the discussion. Archaeological hybrid camel remains represent unique acculturation and internationalization processes that happened in the past. Coming to grips with these processes will require looking into archaeological evidence other than osteological. Camel wrestling provide an ethnoarchaeological guide to define what kind of evidence may relate to activities involving hybrids.

Information from modern day wrestling and its history suggest that although most activities took place outdoors, in wet and cold environments, camels were kept indoors at least throughout the winter. Accumulation of dung, possibly with a high content of bitter vetch or other high energy cereals, is inevitable at these places or near them. Outdoor activities, like camel wrestles, are unlikely to leave any archaeologically visible traces.

Some environmental variables, such as humidity and muddy terrain have a considerable negative effect on the camels' motor skills. A camel caravan is at great risk under heavy rain. Such variables must have influenced the past distribution and abundance of camel related activities. Infants are particularly prone to adverse climates, so it can be surmised that camels were raised in centres located in favourable environmental zones and then sold to buyers from outside those habitats. Whether such exchanges, which would cause greater mobility between distinct geographical areas, took place in the past can be tested using strontium isotopic analyses on molar teeth. Strontium isotopes integrated into an individual's tooth enamel while the individual was still young would give clues about the individual's geographical origins.

Remains of commodities such as lapis lazuli and cowrie beads originating from the Persian Gulf are very likely to be associated with activities relating to camels. Such exotic items may have been used to ornament the camels brought to be exchanged with other goods or they may have been products in their own right brought by camel caravans.

Examined in conjunction with written sources where available, these various lines of materialcultural and zooarchaeological evidence may help establish a firmer time line and geographical map of hybrid camel use and distribution in Anatolia and adjacent regions.

\section{CONCLUSIONS}

Archaeological evidence for hybrid camels in Anatolia has potentially greater significance than lapis lazuli artefacts, the symbol of scholarship on the early exchanges between Middle and Southwest Asia. The occurrence of hybrids in Anatolia and elsewhere in Southwest Asia represents unique acculturation processes initially catalysed by commercial networks. Camels endorse trade and human interaction of an extraordinary kind. The demand for the vigorous hybrid camels promoted specialized trade across the known world until the end of the Middle Ages because of the necessity to bring together pure-bred parents or at least a Bactrian camel stud and a first generation hybrid each and every time they need to be produced. Our ethnographic and ethnohistoric research into the colourful and varied elements of camel wrestles suggest that from early on this trade may have set the scene for trans-religious rituals involving camel wrestles. For caravan owners and investors, wrestling was an efficient way to select the strongest camels to purchase. For others, they were a source of entertainment, a milieu for crosscultural socialization, perhaps even an agora to exchange other exotic or local items.

It is with this kind of model in mind that we should rethink about the archaeology of hybrid camels. In practice this means that two things are essential: To improve the osteomorphological understanding of hybrid camels by applying the methods outlined above, and to improve the contextual appreciation of the camel remains using an integrated approach involving information from archaeobotany, archaeomalacology and material-culture studies. Direct 
dating of remains ascribed to hybrid camels will certainly enhance the chronological sequence of the emergence and spread of hybrid camels.

\section{Acknowledgments}

This paper is based on a presentation given at the "Old World Camelids" session held at the eleventh international conference of the International Council of Archaeozoology in Paris in 2010. Support for this paper presentation came from the EU training network LecHe (Lactase Persistence and the Early Cultural History of Europe). We would like to thank the organizers of the session, Marjan Mashkour and Mark Beech for their work, the session chair, Hans-Peter Uerpmann for his insightful views on Old World camelids, and Evrim Ölçer for delightful conversations on Anatolian ethnology, and above all to the relatives of C. Üzüm from the Özbaş village.

\section{REFERENCES}

Adamova A. T. 2004. - The Iconography of a Camel Fight. Muqarnas 21: 1-14.

Baimuranov A. 1989. - Two Humped Camels, in Dmitriev G.N. \& ERnst L. K. (eds), Animal Production and Health Paper 65. FAO, Rome: 346-351.

BAKER P. 2008. - Economy, Environment and Society at Kilise Tepe, Southern Central Turkey: Faunal Remains from the 1994-1998 Excavations, in VILA E., GouRiCHON L., CHOYKe A. M. \& BuITENHUis H. (eds), Archaeozoology of the Near East VIII: Proceedings of the Eighth International Symposium on the Archaeozoology of Southwestern Asia and Adjacent Areas. Travaux de la Maison de l'Orient et de la Méditerranée 49. Maison de l'Orient et de la Méditerranée, Lyon: 407-430.

BArTosiewicz L. \& DirJeC J. 2000. - Camels in Antiquity: Roman Period Finds from Slovenia. Antiquity 75: 279-285.

BeCKer C. 2008. - Die Tierknochenfunde aus Tall Seh Hamad/Dur-Katlimmu - eine zoogeographischhaustierkundliche Studie, in KüHNE H. (ed.), Umwelt und Subsistenz der assyrischen Stadt Dur-Katlimmu am unteren Habur, Berichte der Ausgrabung von Tall Seh Hamad / Dur-Katlimmu (BATSH) 8. Harrassowitz Verlag, Wiesbaden: 61-131.

BERTHON R. \& MASHKOUR M. 2008. - Animal Remains from Tilbeşar Excavations, Southeast Anatolia, Turkey. Anatolia Antiqua 16: 23-51.
Berthon R. 2013. - New Data on the Exploitation of Animal Resources in the Upper Tigris River Area (Turkey) during the 2nd and 1st Millennia BC, in DE Cupere B., Linselee V. \& Hamilton-Dyer S. (eds.), Archaeozoology of the Near East X: Proceedings of the Tenth International Symposium on the Archaeozoology of Southwestern Asia and Adjacent Areas. Peeters, Leuven.

BoessneCK J. \& VON DEN DRIESCH A. 1975. Tierknochenfunde vom Korucutepe bei Elazig in Ostanatolien (Fundmaterial der Grabungen 1968 und 1969), in VAN LOON M. N. (ed.), Korucutepe I. North-Holland and Elsevier, Amsterdam and New York: 1-219.

BOESSNECK J. \& VON DEN DRIESCH A. 1985. - Knochenfunde aus Zisternen in Pergamon. Institut für Palaeoanatomie, Domestikationsforschung und Geschichte der Tiermedizin der Universität München, München.

Buillet R. W. 1990. - Camel and the Wheel. Columbia University Press, New York.

Buillet R. W. 2009. - Cotton, Climate and Camels in Early Islamic Iran: A Moment in History. Columbia University Press, New York.

BurCKHARDT J. L. 1830. - Notes on the Bedouins and Wahabys. Colburn \& Bentley, London.

Cakirlar C. \& Rossel S. 2010. - Faunal Remains from the 2003-2004 Excavations at Tell Atchana, in Yener K. A. (ed.), Tell Atchana, Ancient Alalakh. Volume 1, The 2003-2004 Excavation Seasons. Koç University Press, Istanbul: 141-143.

ÇALIŞKAN V. 2009. — Geography of a Hidden Cultural Heritage: Camel Wrestles in Western Anatolia. Journal of International Social Research 2(8): 123-137.

ÇELEBI E. 1985. - Seyahatname. İstanbul: Üçdal Yayınları.

Compagnoni B. \& Tosi M. 1978. — The Camel: Its Distribution and State of Domestication in the Middle East during the Third Millennium B.C. in Light of Finds from Shahr-i-Sokhta, in MEADOw R. H. \& ZEDER M. A. (eds), Approaches to Faunal Analysis in the Middle East. Peabody Museum of Archaeology and Ethnology, Harvard University, Cambridge, Mass.: 91-104.

ÇulHA O. 2008. - Kültür turizmi kapsamında destekleyici turistik ürün olarak deve güreşi festivalleri üzerine bir alan çalışması. Journal of Yaşar University 3(12): 815-840.

De Cupere B. 2001. - Animals at Ancient Sagalassos. Evidence of the Faunal Remains, Studies in Eastern Mediterranean Archaeology 4. Brepols, Turnhout.

Deniz E., ÇALişKan T. \& ÖZgüden T. 1965. — Osteological Investigations of the Animal Remains Recovered from the Excavations of Ancient Sardis. Anatolia 8: 49-56.

DiAZ-GARCIA A. 1983. - Un tratado nazari sobre alimentos: al-kalam ala l-agdiya de al-Arbuli, Cuadernos de Estudios Medievales 9-10: 5-91. 
Donlon J. G., Donlon J. H. \& Agrusa J. 2010. Cultural Tourism, Camel Wrestling, and the Tourism 'Bubble' in Turkey, Anatolia An International Journal of Tourism and Hospitality Research 21(1): 29-39.

EGER A. 2010. - Hisn al-Tinat on the Islamic Byzantine Frontier: Synthesis and the 2005-2008 Survey and Excavation on the Cilician Plain (Turkey). Bulletin of American Schools of Oriental Research 357: 49-76.

FABIŠ M. 1996. - Archaeozoological Remains from the Lower Sanctuary. A Preliminary Report on the 1994 Excavations. Studia Troica 6: 217-227.

FAROQHI S. 1988. - 17. yüzyılın ikinci yarısında devecilik ve Anadolu göçebeleri, in IX Türk Tarih Kongresi. Türk Tarih Kurumu, Ankara: 923-932.

GülsÖKEN S. 2010. — Ayırın Develeri. Ege Yayınları, Istanbul.

Halstead P. \& Jones G. 1989. - Agrarian Ecology in the Greek Islands: Time Stress, Scale and Risk. Journal of Hellenic Studies 109: 41-55.

Hongo H. 1994. — Camel Bones from Kaman-Kalehöyük: Introduction of Camels into Anatolia and the Production of Hybrid Camels (in Japanese). KamanKalehöyük 3: 37-54.

Horwitz L. \& Rosen B. 2005. - A Review of Camel Milking in the Levant, in Mulville J. \& OuTrAm A. (eds), The Zooarchaeology of Milk and Fats, Proceedings of the 9th ICAZ Conference of the International Council of Archaeozoology Durham 2002. Oxbow Books, Oxford: 121-131.

Howell-MeurS S. 2001. - Archaeozoological Evidence for Pastoral Systems and Herd Mobility: The Remains from Sos Höyük and Büyüktepe Höyük. International Journal of Osteoarchaeology 11: 321-328.

IKRAM S. \& ÇAKIRLAR C. 2003. - Unpublished Report on Season's Work on the Faunal Remains from Kinet Höyük.

KARACA B. 2008. - 1522-1532 tarihlerinde Menteşe Bölgesi Yörükleri. Furat University Journal of Social Science 18(2): 403-440.

KöHler-Rollefson I. U. 1989. - Zoological Analysis of Camel Skeletons, in SMITH R. H. \& DAY L. P. (eds), Pella of the Decapolis, Vol. 2: Final Report of the College of Wooster Excavations in Area IX. The Civic Complex, 1979-1985.. The College of Wooster, Wooster: 142-164.

KussingeR S. 1988. - Tierknochenfunde von Lidar Höyük in Südanatolien (Grabungen 1979-86). Ph. D. diss., Tierärztlichen Fakültat Ludwig-MaximiliansUniversität, München.

LEESE A. S., 1927. - A Treatise on the One-Humped Camel in Health and in Disease. Haynes \& Son, Stamford.

LenneP VAn H. J. 1870. - Travels in Little-Known Parts of Asia Minor, Vol. II. Van Lennep, New York.

LESBRE F. X. 1903. - Recherches anatomiques sur les Camelidés. Archives du Muséum d'Histoire naturelle de Lyon 8: 1-196.
Mashkour M. 1997. — The Funeral Rites at Mleiha (Sharja-U.A.E.); The Camelid Graves. Anthropozoologica 25-26: 725-735.

MELLET F. 2008. - Etude archéozoologique de deux sites de la moyenne vallée de l'Euphrate (IIème s. av. JC. - VIIIèmes. ap. JC.): Zeugma (chantiers 6,12 et 20) et Apamée (chantiers 1 à 8). Ph. D. diss., Ecole Nationale Vétérinaire, Nantes.

Morales Muniz A., Riquelme J. A. \& Liesau von LETTOW-VORBECK C. 1995. - Dromedaries in Antiquity: Iberia and beyond. Antiquity 69: 368-375. OdDens J. 2009. — Een Vorstelijk Voorland: Gerard Hinlopen op Reis naar Istanbul (1670-1671). Walburg Pers, Zutphen.

Olsen S. J. 1988. - The Camel in Ancient China and an Osteology of the Camel. Proceedings of the Academy of Natural Sciences of Philadelphia 140(1):18-58.

Onar V., Pazvant G., Alpak H., Armutak A., Karamut I., KIZILTAN Z. \& AsAl R. 2010. — İstanbul Yenikap1 Metro ve Marmaray kazılarında ortaya çıkarılan hayvan iskelet kalıntılarının ön inceleme sonuçları. Arkeometri Sonuçlar Toplantısı 25: 79-98.

Peters J. \& VON DEN DriesCH A. 1997. — The TwoHumped Camel (Camelus bactrianus): New Light on its Distribution, Management and Medical Treatment in the Past. Journal of Zoology 242: 651-679.

PETERS J. 1993. - Archaic Millet: Daily Life and Religious Customs from an Archaeozoological Perspective, in Buitenhuis H. \& Clason A. T. (eds), Archaeozoology of the Near East. Proceedings of the First International Symposium on the Archaeozoology of Southwestern Asia and Adjacent Areas. Universal Book Services, Leiden: 88-96.

PETERS J. 1998. — Römische Tierhaltung und Tierzucht: eine Synthese aus archäozoologischer Untersuchung und schriftlich-bildlicher Überlieferung, Passauer Universitätsschriften zu Archäologie 5. Verlag Marie Leidorf, Rahden/Westfalen.

Peters J. 2001. - Aspekte der Domestikations- und Kulturgeschichte des Dromedars (Camelus dromedarius), in Buitenhuis H. \& Prummel W. (eds), Animals and Man in the Past. Essays in honour of Dr. A.T. Clason emeritus professor of archaeozoology Rijksuniversiteit Groningen, the Netherlands, ARCPublicatie 41. Archaeological Research \& Consultancy, Groningen: 330-341.

Pigière F. \& Henrotay D. 2012. - Camels in the Northern Provinces of the Roman Empire. Journal of Archaeological Science 39 (5): 1531-1539.

PoтTs D. T. 2004. - Camel Hybridization and the Role of Camelus bactrianus in the Ancient Near East. Journal of the Economic and Social History of the Orient 47(2): 143-165.

Reitz E. \& Wing E. 2008. - Zooarchaeology, Cambridge Manuals in Archaeology. Cambridge University Press, Cambridge.

Rousseau G., Guintard C. \& Abadie-Reynal C. 
2008. — La gestion des animaux à Zeugma (Turquie): étude des restes fauniques du chantier 9 (époques hellénistique, romaine, byzantine et islamique). Revue de Médecine Vétérinaire 159: 251-275.

ROUSSEAU G. 2006. - Les restes fauniques du site de Zeugma (Turquie) : étude archéozoologique du chantier 9. Ph. D. diss., Ecole Nationale Vétérinaire, Nantes.

SAPIR-Hen L. \& Ben-Yosef E. 2013. - The Introduction of Domestic Camels to the Southern Levant: Evidence from the Aravah Valley. Tel Aviv 40: $277-85$.

Silitlibolaz D. 2009. - Animal Bone Studies on Byzantine City of the Amorium. MA. diss., Middle Eastern Technical University, Ankara.

Skidmore J. A., Morton K. M. \& Billah M. 2010. Unique Strategies to Control Reproduction in Camels. Reproduction in Domestic Ruminants 7(1): 465-472.

STAHL U. 1989. - Tierknochenfunde vom Hassek Höyük (Südostanatolien). Ph. D. diss., Tierärztlichen Fakültat Ludwig-Maximilians-Universität, München.

STEIGER C. 1990. - Vergleichend morphologische Untersuchungen an Einzelknochen des poscranialen Skeletts der Altweltkamele. Ph. D. diss., Tierärztlichen Fakültat Ludwig-Maximilians-Universität, München.

SteIN G. J. 1988. — Pastoral Production in Complex Societies: Mid-Late Third Millennium B.C. and Medieval Faunal Remains from Gritille Höyük in the Karababa Basin, Southeast Turkey. Ph. D. diss., Department of Anthropology, University of Pennsylvania, Philadelphia.

Studer J. \& SCHNeIder A. 2008. - Camel Use in the Petra Region, Jordan: 1st century BC to 4th century
AD, in Vila E., Gourichon L., Choyke A. M. \& Buitenhuis H. (eds), Archaeozoology of the Near East VIII: Proceedings of the Eighth International Symposium on the Archaeozoology of Southwestern Asia and Adjacent Areas. Travaux de la Maison de l'Orient et de la Méditerranée 49. Maison de l'Orient et de la Méditerranée, Lyon: 581-596.

TAPPER R. 1985.- One Hump or Two? Hybrid Camels and Pastoral Cultures. Production pastorale et société 16: 55-69.

Uerpmann H. -P. 1999. — Camel and Horse Skeletons from Protohistoric Graves at Mleiha in the Emirate of Sharjah (U.A.E.). Arabian Archaeology and Epigraphy 10: 102-118.

ÜzÜм C. 2003. - Devecinin Günlü̆̆̈̈. Cumhuriyet Ofset, Söke.

VogLer U. 1997. - Faunenhistorische Untersuchungen am Sirkeli Höyük, Adana, Turkei. Ph. D. diss., LudwigMaximilians-Üniversität, München.

WAPNISH P. 1984. - The Dromedary and Bacrian Camel in Levantine Historical Settings: The Evidence from Tell Jemmeh, in ClutTON-Brock J. \& Grigson C. (eds), Animals and Archaeology, Vol. 3: Early Herders and their Flocks, BAR International Series 163. British Archaeological Reports, Oxford: 171-200.

Wilson T. R. 1984. — The Camel. Longmann, London $\&$ New York.

YAGIL R. \& ETZION Z. 1980. - Hormonal and Behavioural Patterns in the Male Camel (Camelus dromedaries). Journal of Reproduction and Fertility 58(1): 61-5.

ZoHARY D. \& Hopf M. 2000. - Domestication of Plants in the Old World. Oxford University Press, Oxford.

Submitted on December 2013; accepted on March 2014. 